\title{
Analyzing the Economic Development Using Partial Least Square Structural Model: A Case of Narok, Kenya
}

\author{
Otieno Okumu Kevin, Samuel Muthiga Nganga \\ Department of Mathematics and Physical Sciences, Maasai Mara University, Narok, Kenya
}

Email address:

Kevinotieno15@gmail.com (O. O. Kevin),muthiga@mmarau.ac.ke(S. M. Nganga)

To cite this article:

Otieno Okumu Kevin, Muthiga Samuel. Analyzing the Economic Development Using Partial Least Square Structural Model: A Case of Narok, Kenya. Science Journal of Applied Mathematics and Statistics. Vol. 9, No. 2, 2021, pp. 33-43. doi: 10.11648/j.sjams.20210902.11

Received: December 18, 2020; Accepted: December 25, 2020; Published: March 13, 2021

\begin{abstract}
After the establishment of the Narok County government and the transition from the central system of government into the Devolved system of governance, majority of the residents of Narok County had much anticipation in terms of developments that will take place as a result of governance being brought close to them. The study was checking economic development changes that has taken place in Narok Town the Headquarter of Narok County since the establishment of the Narok County Government. The objective was to access how the introduction of county government has impacted on the economic development by investigating its impact on the various key indicators of the economic development such as health, trade, and infrastructure. The study used a sample of 320 residents drawn at random from all parts of the town, the samples was surveyed using a written survey instrument and their opinion on the state of various economic indicators was captured and used to develop a structural equation model using SmartPLS 3 software, in order to use in examining the economic development status of Narok Town. The study fits a significant model that can tell the whereabouts of the economic status of the Town presently and in future. It was concluded that the county government has not done much in terms of economic development since the introduction of County government because the rural areas in the county are still struggling to catch up with the indicators of economic development. It was also evidenced that the impact of County government on trade is good compared to its impact on health and infrastructure.
\end{abstract}

Keywords: Economic Development, Trade, Health, Infrastructure

\section{Introduction}

After inauguration of the new constitution in the year 2010, the country government system was transformed from a central form of government into devolved government system, this ensured the distribution of the initial power held by the national government to the 47 county governments. This in return, brought about the distribution of responsibilities from the National Government to the County Government $[1,5,18]$. One of the responsibilities which was given to the county government based on the initial objective of the new form of government of bringing the resources closer to the citizens, was the responsibility county government to take charge in the development of their own counties. The responsibility, ensured that each county had a hand/say in the development of the economy of all areas under its jurisdiction, this is in contrary to the initial form of government where majority of the development responsibility had rested with the
National/Central government.

Economic development are activities which to improve the economic well-being and quality of life of a community [2, 3, $6,9]$. According to the world Bank which is the main body uphold with the responsibility of measuring the economic development of countries [9], the international economic development can be measured by; Economic Policy and Debt, Financial Sector, Private Sector and Trade, Public Sector, Poverty, Education, Environment, Labor, Health and Infrastructure $[4,10]$.

After transition into the County Government system, after the implementation of the New Constitution dispensation and the establishment of the Narok County Government in the 2013. Majority of the residents of the county had profound level of hopes, for a new change and growth of the economy of the county. For this reason, the study examined if there 
had been a change in the economic development of Narok Town as a result of the introduction of the county government by analyzing the economic development in terms of trade, health and infrastructure.

\subsection{Health}

According to the health statistics 2014 , only $18.1 \%$ of the births in Narok County are delivered in Hospitals [5, 11]. The county has 84 Dispensaries, 16 Health Centers, 1 SubDistrict Hospital and 3 District Hospitals, the Doctor to patient ratio in the county is 1:100953, the best public health facilities are Narok District Hospital which has a capacity of 155 beds followed by Transmural District Hospital with a capacity of 32 beds [11].

In terms of prevalence of the most common diseases in the county, Malaria Case prevalence is 12,300 per 100,000 and TB prevalence is 159 per 100,000 [11].

The county has 61 water pans, and only 53 are operational, 7 permanent springs, 4 permanent rivers and 7 operational boreholes $[17,18]$. The county does not have a centralized piping sewer system, most of the urban residents rely on pit latrines while majority of the residents in rural areas commonly defecate in the bushes, majority of the residents contaminates the rivers by washing cars, motorbikes and cloths in them $[5,15]$.

\subsection{Trade}

The major economic activities of members of Narok County are Commercial Farming of wheat, Maize and Potato,
Tourism at Maasai Mara and Livestock farming [6, 7, 16], majority of the residents of Narok County do trade in agricultural products. The market price of livestock is such that medium size cattle is Kshs 17,600/= in Narok County while a two years old goat ranges from Kshs 3,450 to Kshs $3,560[10,14]$.

\subsection{Infrastructure}

The infrastructure of Narok County Composes of Narok composes of roads, access to sources of energy, communication and proper drainage or sewer system. Only $6 \%$ of the residents of Narok County, uses electricity as their main source of energy for lighting, 29\% use lanterns, 54\% use tin lamps and $8 \%$ uses wood $[3,10,15]$. In terms of source of energy for cooking, $1 \%$ of residents in Narok County use liquefied petroleum gas (LPG), and 2\% use paraffin. $80 \%$ use firewood and $17 \%$ use charcoal [15]. $4.6 \%$ of the county roads are paved, while $41.6 \%$ of the county roads are in good status [8].

\section{Mathematical Formulation}

\subsection{Structural Equation Model}

The variables under investigation namely; trade, health and infrastructure can be represented in a model chart as shown in Figure 1. The chart shows the overall relationship and the inter-variable relationships.

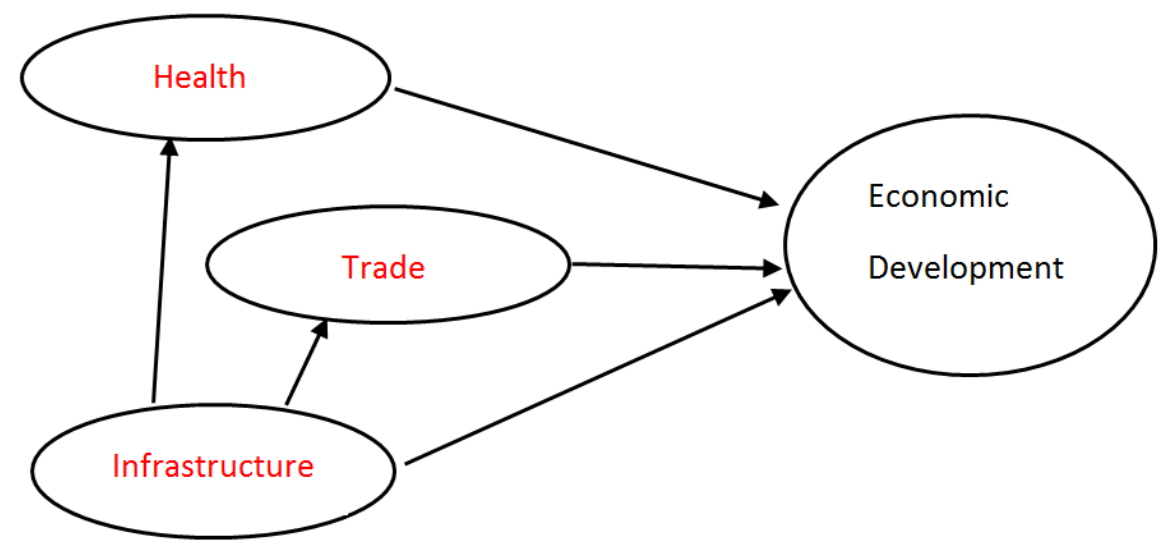

Figure 1. Chart for Structural Equation model.

\subsection{Model Variables}

In the inner structure the independent latent variables are Trade, Infrastructure, and Health. The dependent variable is Economic development. Among the latent independent variables, the study assumes that all the variables are endogenous, with infrastructure assumed to be influencing health, and trade.

\subsection{Model Equation}

The main regression equation in the model is a linear regression equation which is assumed to exist between the independent variables and the dependent variable. The equation is given by

$$
E c d=\beta_{0}+\beta_{1} \operatorname{Tr}+\beta_{2} \operatorname{Inf}+\beta_{3} \text { Hea }+e_{i}
$$

Where; Ecd - Economic development

Inf - Infrastructure

Hea - Health

Tr - Trade

e - Error term

B - Regression coefficient 
The study also assumes that there do exist a linear relationship between;

Infrastructure and trade given by the mode

$$
\operatorname{Tr}=\beta_{0}+\beta_{1} \operatorname{Inf}+e_{i}
$$

\subsection{Test for Adequacy of Individual Parameter}

The test for the adequacy of the individual parameter/path coefficients in the model shall be tested using the Hotkings individual $\mathrm{t}$-test $(\mathrm{T})$, which is given by;

$$
T=\frac{\beta_{i}}{S \cdot E\left(\beta_{i}\right)}
$$

Where S.E is the square-root of the variance of the individual parameter from the variance covariance matrix.

\subsection{Goodness of Fit Test}

The goodness of fit test of the model shall be tested using the chi-square likelihood goodness of fit test.

\section{Results}

\subsection{Health}

Table 1 shows the ratings of various health issues, concerning Narok town since the establishment of the Narok County Government;

\begin{tabular}{|c|c|c|c|c|c|}
\hline & Strongly Disagree & Disagree & Neutral & Agree & Strongly Agree \\
\hline & $\begin{array}{l}\text { Percentage } \\
\text { Proportion } \\
\end{array}$ & $\begin{array}{l}\text { Percentage } \\
\text { Proportion } \\
\end{array}$ & $\begin{array}{l}\text { Percentage } \\
\text { Proportion } \\
\end{array}$ & $\begin{array}{l}\text { Percentage } \\
\text { Proportion } \\
\end{array}$ & $\begin{array}{l}\text { Percentage } \\
\text { Proportion } \\
\end{array}$ \\
\hline Health services has improved & 14 & 23 & 28 & 28 & 7 \\
\hline Access to medical care has improved & 7 & 26 & 32 & 31 & 5 \\
\hline Improved condition of health care facilities & 7 & 19 & 48 & 21 & 5 \\
\hline Reduced disease outbreaks & 11 & 37 & 40 & 8 & 5 \\
\hline Adequate supply of clean water & 16 & 54 & 16 & 10 & 4 \\
\hline Reduced treatment cost at the hospitals & 11 & 30 & 26 & 29 & 4 \\
\hline Adequate supply of drugs at the hospitals & 24 & 22 & 20 & 30 & 4 \\
\hline
\end{tabular}

Table 1. Health matters rating table.

It can be observed from the table 1 that;

I. $\quad 37 \%$ of the individuals living in Narok town, are of the opinion that, health services at the government hospitals within Narok Town has not improved, 35\% are of the opinion that it has improved while the remaining $28 \%$ area unaware of anything, this shows that, though much has been done in terms of health service provision, quiet a number of residents are still not contented with the same.

II. Majority of the individuals $(36 \%)$ are of the opinion that access to medical care has improved in the town, this shows that the county government has been able to bring medical care closer to the members of the Town.

III. $48 \%$ of the individuals are unaware if the conditions of the health care facilities has improved or not, this shows that few of the residence have been exposed to the changes that has taken place in terms of the condition of the health facilities.

IV. Majority of the residence (48\%) are of the opinion that, the disease outbreak in the town has not reduced, this shows that, little emphasis has been made by the county government, in order to try and change the same.

V. $70 \%$ of the residents are of the opinion that, there is still no supply of clean water in the town, this shows that very little has been done by the county government on the basis of supply of clean water to the residents of Narok Town.

VI. Majority of the residents (41\%) are of the opinion that, the medical cost at the hospitals are still high to the common town resident, this shows that despite the much which has been done to make health care affordable, the cost of medical care is still out of reach to some residents.

VII. Majority of the residents (46\%) are still of the opinion that, there is no adequate supply of drugs to the public hospital in the town, this shows that, there are still some drugs that are required by the patients in the hospitals at some point but are unavailable to them.

In general, it can be observed that, apart from access to medical care, all the other health components have still not been improved to the satisfaction of Majority of the residents.

Figure 2 shows the general rating of the health status improvement by the town residents;

\section{STATUS OF NAROK TOWN HEALTH SINCE THE ESTABLISHMENT OF NAROK COUNTY GOVERNMENT}

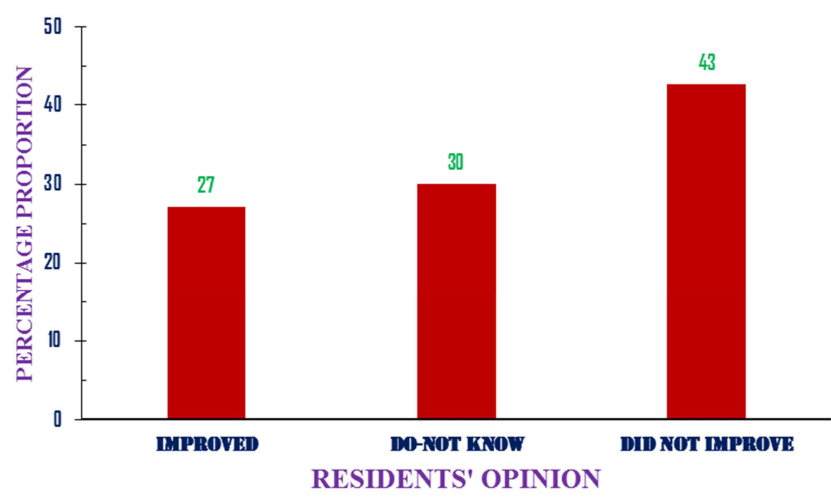

Figure 2. Overall health rating graph.

It can be observed that Majority of the residents (43\%), are 
not satisfied with the improvement that has taken place in the health sector in the town, this shows that, much still needs to be done in-order to change the same. Therefore, it can be generally concluded that health has only improve by $27 \%$ since the establishment of the County government.

\subsection{Trade}

Table 2 shows the improvement rating of various trade components in the Town since the establishment of Narok County government.

Table 2. Trade issues rating table.

\begin{tabular}{|c|c|c|c|c|c|}
\hline & Strongly Disagree & Disagree & Neutral & Agree & Strongly Agree \\
\hline & $\begin{array}{l}\text { Percentage } \\
\text { Proportion } \\
\end{array}$ & $\begin{array}{l}\text { Percentage } \\
\text { Proportion } \\
\end{array}$ & $\begin{array}{l}\text { Percentage } \\
\text { Proportion } \\
\end{array}$ & $\begin{array}{l}\text { Percentage } \\
\text { Proportion } \\
\end{array}$ & $\begin{array}{l}\text { Percentage } \\
\text { Proportion } \\
\end{array}$ \\
\hline Increased number of businesses & 7 & 15 & 36 & 27 & 15 \\
\hline Reduced cost of doing business & 15 & 15 & 34 & 33 & 3 \\
\hline Improved business security & 13 & 37 & 34 & 15 & 1 \\
\hline Improved business market & 7 & 13 & 27 & 47 & 7 \\
\hline Reduced business taxation & 36 & 31 & 27 & 3 & 3 \\
\hline
\end{tabular}

Table 2 shows that;

i. Majority of the residents $(42 \%)$ believe that, the number of businesses in the town has increase, this shows that viable conditions have been made by the county government for the establishment of new businesses.

ii. $36 \%$ of the residents believe that, the cost of doing business in Town has reduced, this shows that, the county government has somehow slightly reduced some of the business costs in town.

iii. $50 \%$ of the residents feel that, the security of businesses in town has not improved, this shows that very little has been done in terms of security matters in town by the county government.

iv. Majority of the residents (54\%) feel that the town's business market has improved, this shows that the government has been able to widen the market of various commodities in the town.

v. In terms of taxation, $67 \%$ of the residents are of the view that the business taxation has not reduced, rather majority say that the business taxation has increased, this shows that the county government has introduced or increased some of the original existing business taxes.

In general, table 2 shows that trade in the town has improved to some extent. On the overall trade improvement rating, Figure 3 shows the general trade improvement rating;

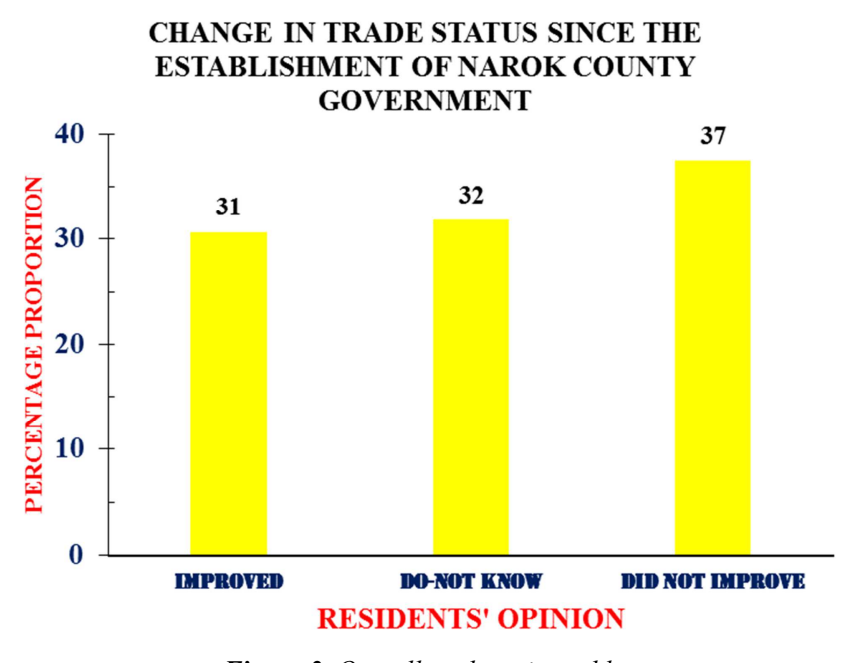

Figure 3. Overall trade rating table.

The rating is not so much apart for the improvement and lack of improvement, this shows that trade has averagely grown in the town after the establishment of the County Government.

\subsection{Infrastructure}

Table 3 shows the rating of various infrastructural aspect of the town since the establishment of the county government;

Table 3. Infrastructural issues rating table.

\begin{tabular}{|c|c|c|c|c|c|}
\hline & Strongly Disagree & Disagree & Neutral & Agree & Strongly Agree \\
\hline & $\begin{array}{l}\text { Percentage } \\
\text { Proportion }\end{array}$ & $\begin{array}{l}\text { Percentage } \\
\text { Proportion }\end{array}$ & $\begin{array}{l}\text { Percentage } \\
\text { Proportion }\end{array}$ & $\begin{array}{l}\text { Percentage } \\
\text { Proportion }\end{array}$ & $\begin{array}{l}\text { Percentage } \\
\text { Proportion }\end{array}$ \\
\hline Improved communication system & 11 & 39 & 9 & 36 & 5 \\
\hline Improvement in the recreational facilities & 19 & 35 & 37 & 5 & 4 \\
\hline Improved access to electricity & 10 & 28 & 12 & 43 & 7 \\
\hline
\end{tabular}

Table 3, illustrates that;

I. Majority of the residents $(50 \%)$, believe that the mobile network connection in the town has not improved, this illustrates that there is still an average number of residents who still have hard time communicating through mobile phones in the town.
II. $74 \%$ of the residents, are of the opinion that, the transport network of the town has not improved, this shows that the government has done very little in terms of transport system improvement in the town, therefore some areas of the town are still in accessible due to poor transport system. 
III. Majority of the residents (54\%) are of the opinion that the recreational facilities of the town have not improved in status, this shows that, what has been done by the county government in terms of improvement of recreational facilities is little to be noted by majority of the residents.

IV. $50 \%$ of the residents are of the opinion that access to electricity has improved among the town residents, the shows that quiet a good number of the residents who live in the town have access to electricity and therefore the government has aided in the same.

Therefore, apart from rural electrification, less has been done in the town by the county government in terms of infrastructural development. Figure 4 shows the general of the residents as infrastructural improvement is concerned;

\section{STATUS OF INFRASTRUCTURE OF NAROK TOWN SINCE THE ESTABLISHMNET OF NAROK COUNTY GOVERNMENT}

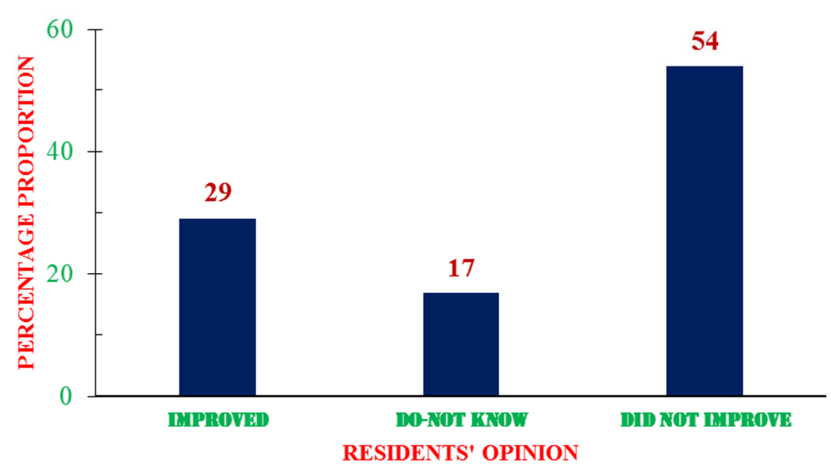

Figure 4. Overall infrastructure rating chat.

Figure 3 illustrates that not much has been done in terms of infrastructural development in the town by the county government.

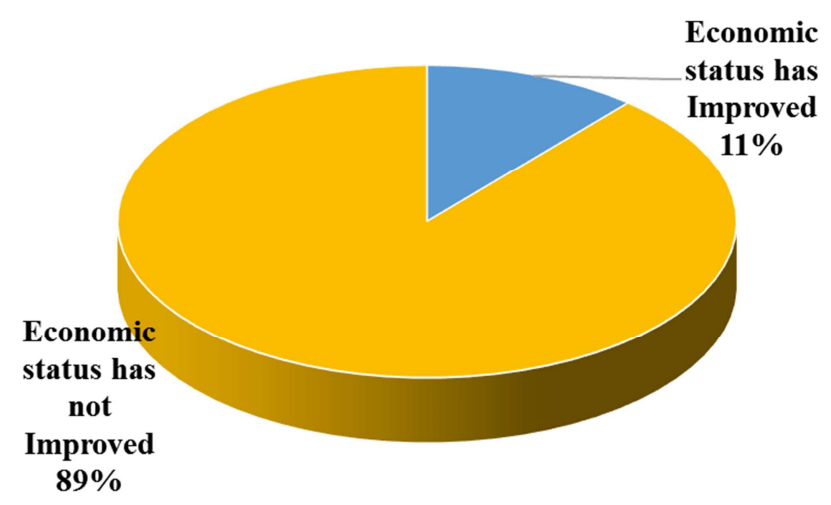

Figure 5. Overall economic growth rating chart.

\subsection{Economy}

In terms of the general economic development status of the town, $89 \%$ of the residents are of the opinion that the economic status of the town has not improved since the establishment of the Narok County government.

This shows that, less has been done by the county government of Narok County to improve the economic status of Narok Town.

\subsection{Determinants of Economic Development}

In the study, it was found out that, in Narok town, the residence view on economic development is associated with the equivalent development of;

I. Level of health development of the town (Chisquare $=81.096, \mathrm{Df}=1, \mathrm{P}$-value $<0.001)$. This illustrates that if the health sector of the town develops, the residents will view the economy as to have developed in return. If a resident observes that the health sector of the town to have developed, he/she is 16.333 times more likely to view the economy of the town to have developed as compared to a person who feel that the health care has not. The $95 \%$ confidence interval for the odds is (7.069 $\leq$ odds $\leqq 37.739)$.

II. The level of development of trade in the town (Chisquare $=61.644, \mathrm{Df}=1, \mathrm{P}$-value $<0.001$ ). Therefore, if the trade of the town is viewed by the residents to have developed, then they will view the economy also to have developed. A resident who view the trade of the town to have developed is 0.717 time likely to pledge that the economy of the town in general has not developed as compared to a person who view the trade sector has to have not developed. The $95 \%$ confidence interval for the ratio of the two probabilities is $(0.642 \leq$ odds $\leq 0.799)$.

III. Improvement in infrastructure (Chi-square $=106.898$, $\mathrm{Df}=1$, P-value $<0.001)$. This illustrates that the more the town's infrastructure develop, the more the resident will view the economy of the town to have developed. A person who feel that the infrastructure of the town has developed is 13.348 times likely to view that the economy of the town has developed too as compared to one who view the infrastructure has to have not developed. The $95 \%$ confidence interval for the ratio is $(9.01 \leq$ odds $\leq 19.775)$.

\subsection{The Structural Equation Model}

The study was able to fit a structural equation model that relates the Three Economic Indicators thus, Health, Infrastructure and Trade. And their ability to predict the view of the residence of Narok Town on the Economic Development of the town. The model aimed at coming up with a model that can use the ratings of the residents on the indicators and the development of the town's economy. The following partial least square structural equation model was able to be fitted. 


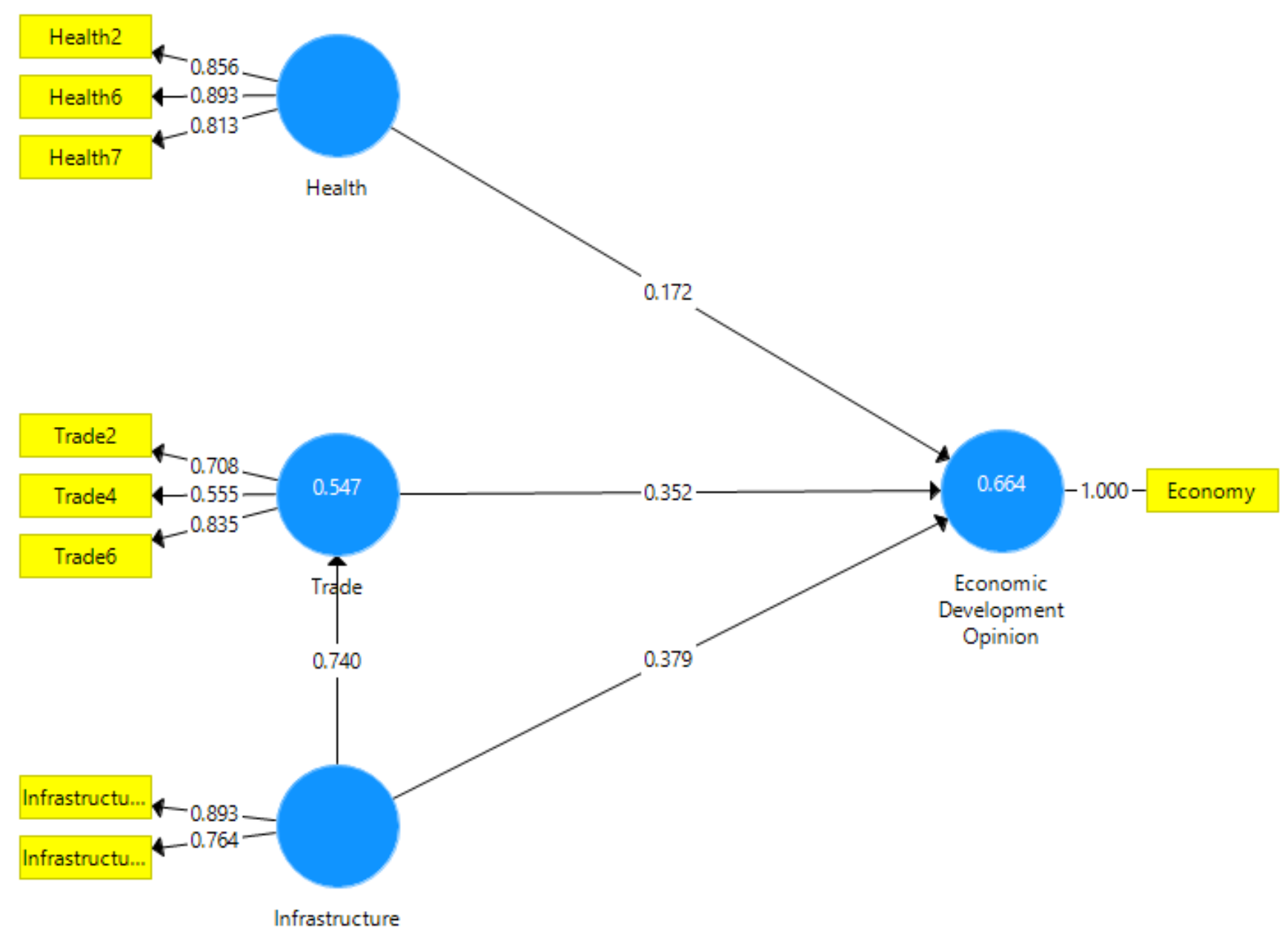

Figure 6. Model.

\subsubsection{Model Reliability Test}

\section{(i) Indicators Test}

All the model indicators have coefficient values which are more than 0.5 this is above the acceptable value of 0.5 . This as a result shows that all the indicators are significant.

Table 4. Indicator test.

\begin{tabular}{|c|c|c|c|c|}
\hline & Economic Development Opinion & Health & Infrastructure & Trade \\
\hline Economy & 1.000 & & & \\
\hline Health2 & & 0.856 & & \\
\hline Health6 & & 0.893 & & \\
\hline Health7 & & 0.813 & & \\
\hline Infrastructure2 & & & 0.893 & \\
\hline Infrastructure4 & & & 0.764 & \\
\hline Trade2 & & & & 0.708 \\
\hline Trade4 & & & & 0.555 \\
\hline Trade6 & & & & 0.835 \\
\hline
\end{tabular}

Table 4 shows that all the indicators in the model are reliable.

\section{(ii) Internal Latent Variable Consistency and Reliability Test}

For the test of consistency of the latent variable in the study, the Composite reliability test was used. As show in Figure 7: 


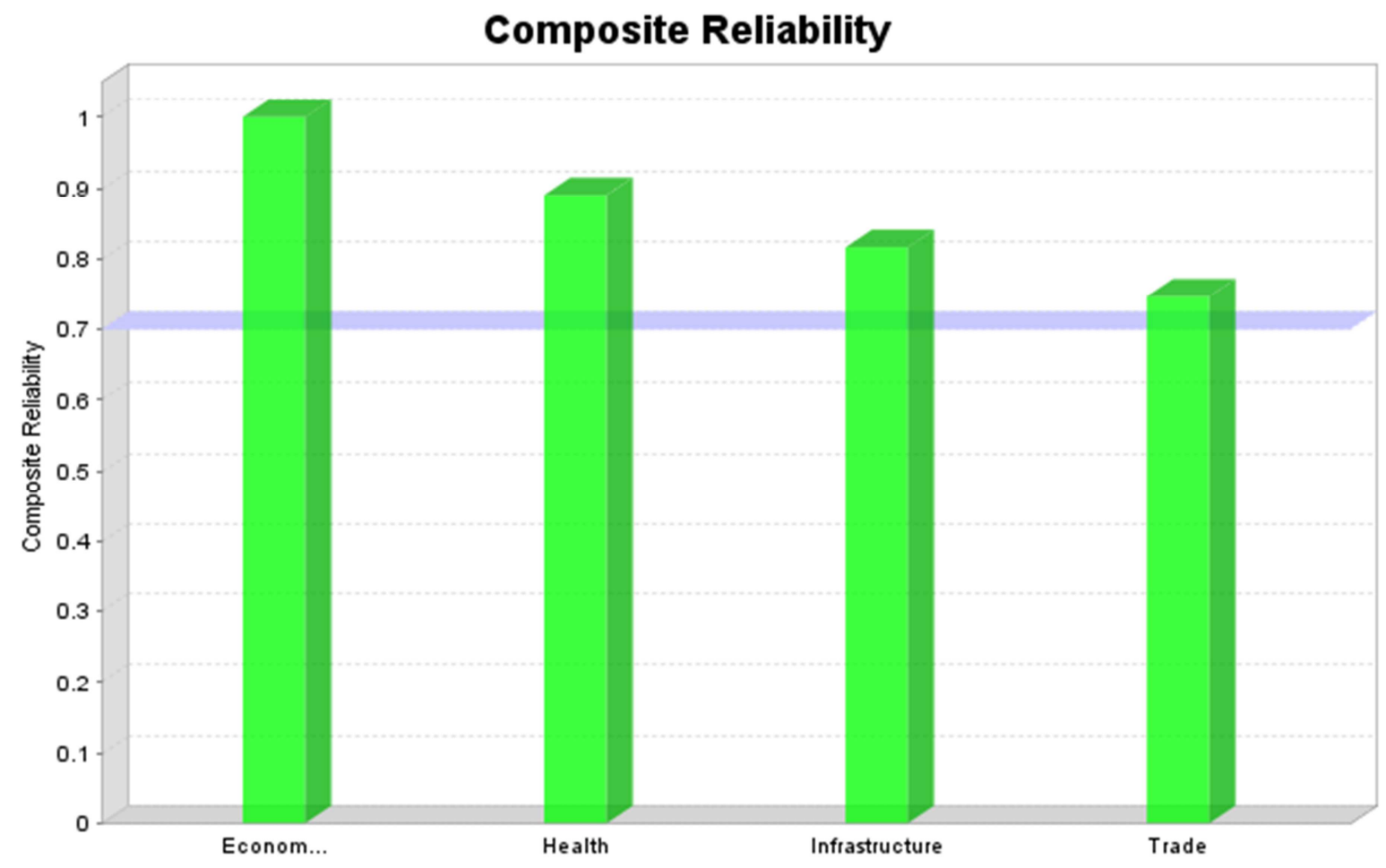

Figure 7. Internal latent variable consistency and reliability test.

The test shows that all the variable pass the Consistency and Reliability test of 0.7 threshold. Hence all the latent variable is consistent and reliable enough to be used in the study.

\section{(iii) Convergent Validity}

To test the validity of the model fitting convergence of the latent variables, the study used the Average Variance Extract to check on the validity of the convergence. The minimum acceptable value of AVE is 0.5 . According to Figure 8 , the convergence of all the latent variables was valid.

\section{Average Variance Extracted (AVE)}

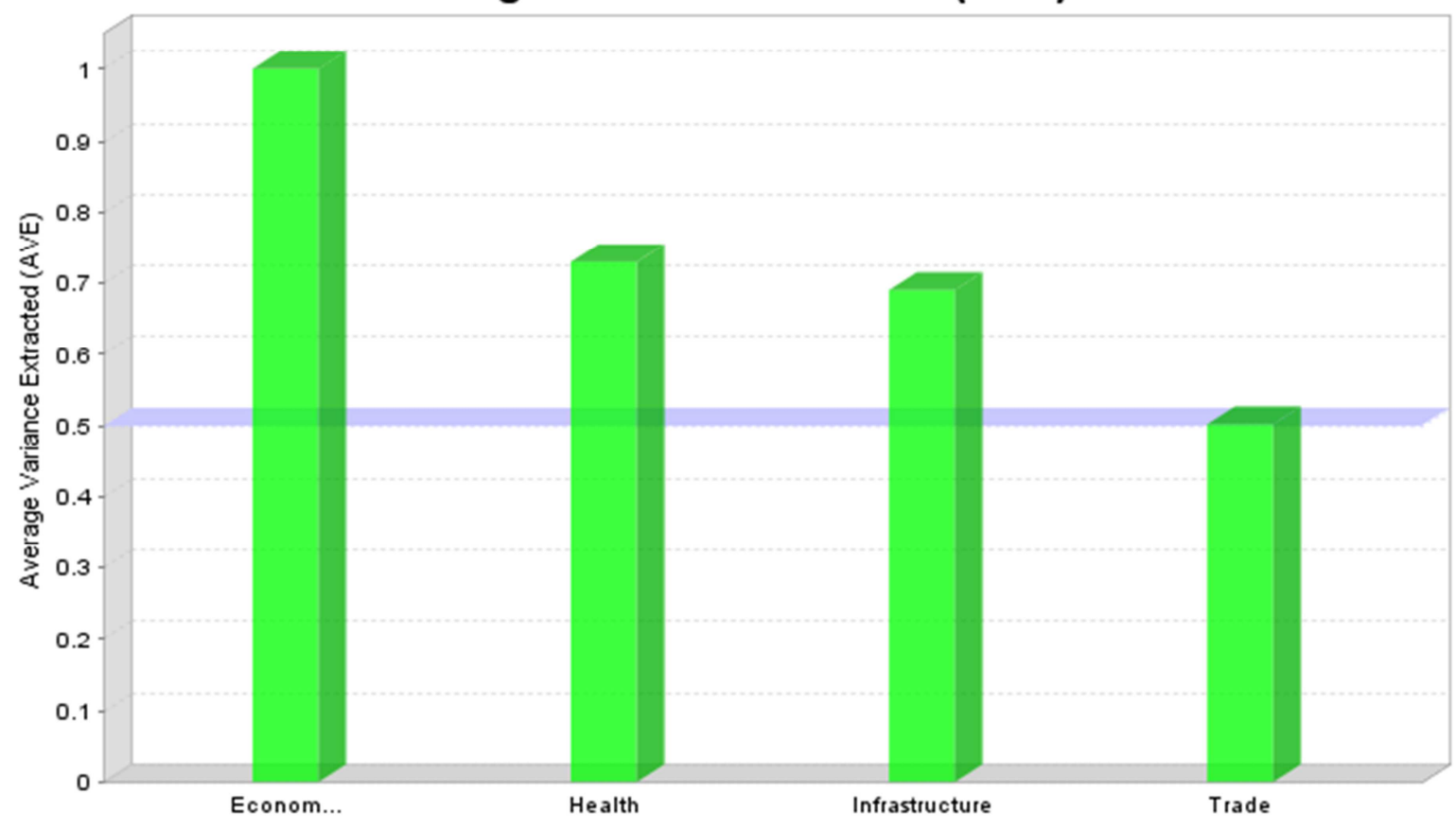

Figure 8. Convergent validity test. 


\section{(iv) Discriminant Validity}

According to Fornell and Larcker 1981, suggested the square-root of AVE in each latent Variable can be used to establish discriminant validity. Table 5 shows that all the variables satisfy the discriminant validity test:

Table 5. Fornell and Larcker criterion.

\begin{tabular}{|c|c|c|c|c|}
\hline & Economic Development Opinion & Health & Infrastructure & Trade \\
\hline Economic Development Opinion & 1.000 & & & \\
\hline Health & 0.665 & 0.854 & & \\
\hline Infrastructure & 0.755 & 0.672 & 0.831 & \\
\hline Trade & 0.749 & 0.678 & 0.740 & 0.709 \\
\hline
\end{tabular}

This shows that all the model variables satisfy all the variable test, hence qualify to be used in the model.

\subsubsection{Model Coefficient Analysis and Test}

\section{(i) Model Coefficients}

Figure 9 shows the model coefficients

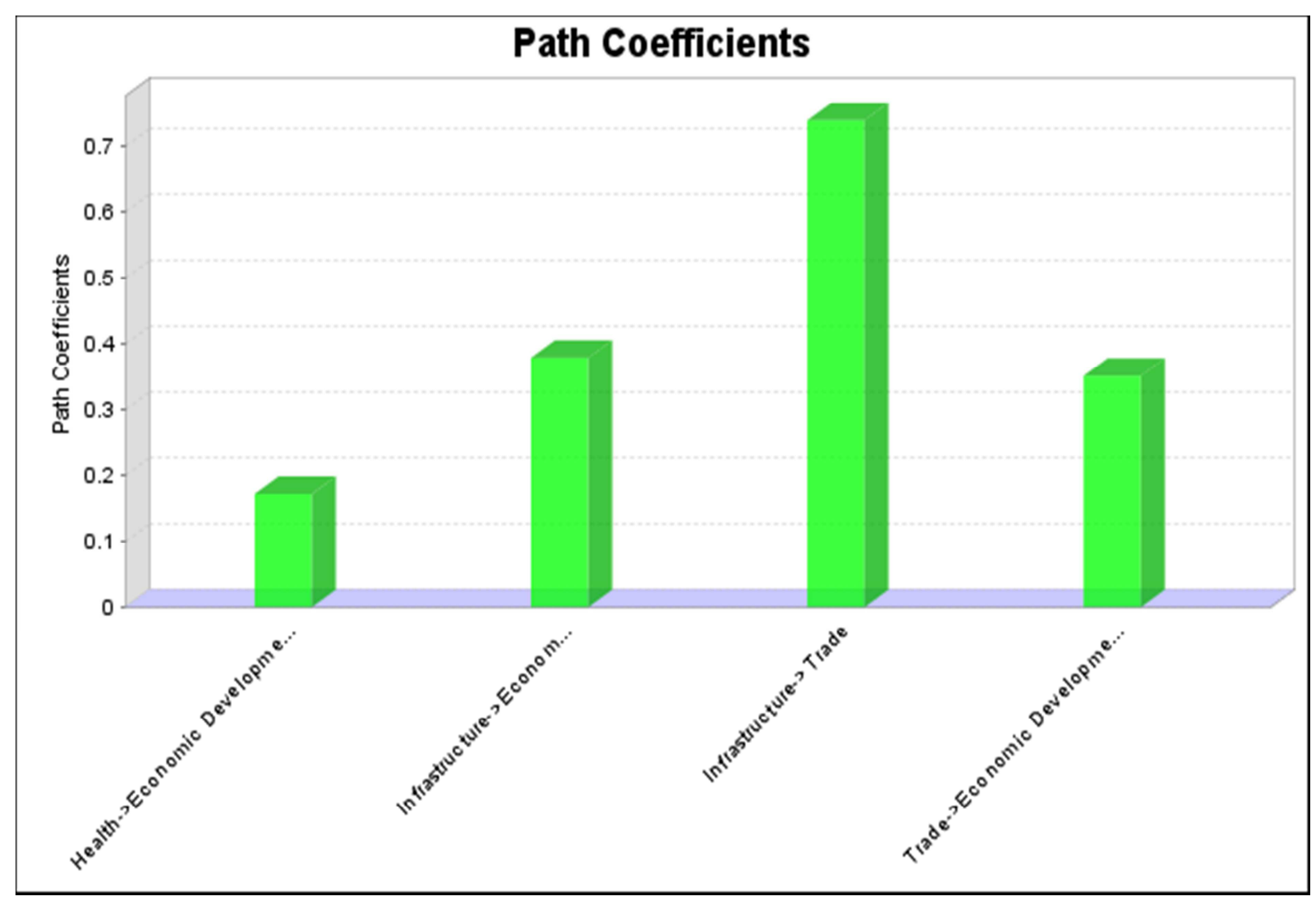

Figure 9. Path coefficients.

From the above table it can be seen that Infrastructure has a very strong effect on trade. In terms on the effect of economic development, Majority of the resident's view that infrastructure is the biggest indicator of economic development, followed by trade and lastly health.

This shows that the more the infrastructure is developed in the town, the more the members of the town would view the economy to have developed. Therefore, if the county government want to score more in terms of economic development, they need to emphasize more on infrastructural development.

\section{(ii) Model Coefficient Test}

The test of the coefficients using the T-test based on the hypothesis:

$$
\mathrm{H}_{0}: \beta_{\mathrm{i}}=0
$$

Against

$$
\mathrm{H}_{1}: \beta_{1} \neq 0
$$

The test shows that all the model coefficients are significant: 
Table 6. Model coefficient test.

\begin{tabular}{|c|c|c|c|c|c|}
\hline & $\begin{array}{l}\text { Original } \\
\text { Sample (O) }\end{array}$ & $\begin{array}{l}\text { Sample } \\
\text { Mean (M) }\end{array}$ & $\begin{array}{l}\text { Standard Deviation } \\
\text { (STDEV) }\end{array}$ & $\begin{array}{l}\text { T Statistics } \\
(\mid \mathbf{O} / \text { STDEV } \mid)\end{array}$ & P Values \\
\hline Health -> Economic Development Opinion & 0.172 & 0.169 & 0.045 & 3.854 & 0.000 \\
\hline Infrastructure -> Economic Development Opinion & 0.379 & 0.383 & 0.050 & 7.573 & 0.000 \\
\hline Infrastructure -> Trade & 0.740 & 0.742 & 0.029 & 25.289 & 0.000 \\
\hline Trade -> Economic Development Opinion & 0.352 & 0.353 & 0.047 & 7.448 & 0.000 \\
\hline
\end{tabular}

Since all the coefficients are significant, hence all the effects attributed by the latent variables on the respective dependent variables is significant.

The $95 \%$ confidence interval is shown in the table 7 below:

Table 7. Confident Interval.

\begin{tabular}{lllll}
\hline & Original Sample (O) & Sample Mean (M) & $\mathbf{2 . 5 \%}$ & $\mathbf{9 7 . 5 \%}$ \\
\hline Health -> Economic Development Opinion & 0.172 & 0.169 & 0.079 & 0.250 \\
Infrastructure -> Economic Development Opinion & 0.379 & 0.383 & 0.287 & 0.489 \\
Infrastructure -> Trade & 0.740 & 0.742 & 0.682 & 0.792 \\
Trade -> Economic Development Opinion & 0.352 & 0.353 & 0.261 & 0.449 \\
\hline
\end{tabular}

\subsubsection{Model Significance}

To check on the significance/importance of the model, the study used the R-squared, this is displayed in Figure 10:

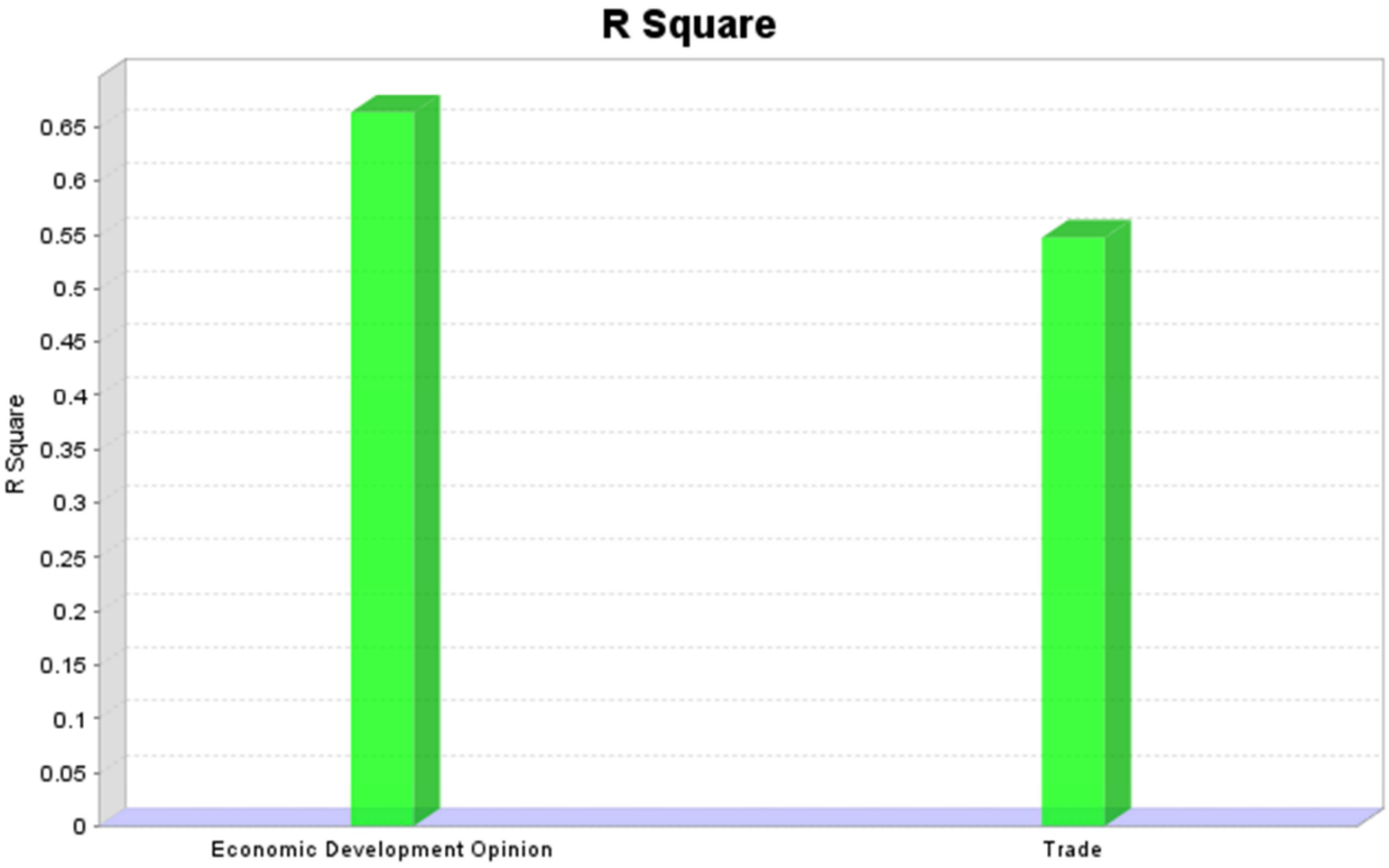

Figure 10. $R$ square statistics.

From it can be observed that Health, Infrastructure and Trade development can illustrate $66.4 \%$ of the variation in the economic development of the town. And it can be observed that Infrastructure development contribute to $54.7 \%$ of the variation in trade development. The coefficient of determination is significant. This is based on the T-test with null and alternative hypothesis as follows:
$\mathrm{H}_{\mathrm{o}}$ : the coefficient of determination is equivalent to zero Against

$\mathrm{H}_{1}$ : the coefficient of determination is not equivalent to zero

The test statistics shows that the coefficient of determination in the model are all significant:

Table 8. Test of coefficients.

\begin{tabular}{llllll}
\hline & Original Sample (O) & Sample Mean (M) & Standard Deviation (STDEV) & T Statistics (|O/STDEV|) & P Values \\
\hline Economic Development Opinion & 0.664 & 0.670 & 0.036 & 18.227 & 0.000 \\
Trade & 0.547 & 0.551 & 0.043 & 12.680 & 0.000 \\
\hline
\end{tabular}


The table below also displays the $95 \%$ confidence interval for the coefficients

Table 9. Confidence interval.

\begin{tabular}{lllll}
\hline & Original Sample (O) & Sample Mean (M) & $\mathbf{2 . 5 \%}$ & $\mathbf{9 7 . 5 \%}$ \\
\hline Economic Development Opinion & 0.664 & 0.670 & 0.602 & 0.739 \\
Trade & 0.547 & 0.551 & 0.465 & 0.628 \\
\hline
\end{tabular}

\subsubsection{Regression Equation and Interpretation}

From the structural equation model, based on the given sets of latent variables, two sets of Least Square linear equation model can be generated from the model:

$$
\text { Trade }=0.740 \text { Infrastructure }
$$

From this equation, it can be observed that $100 \%$ improvement in Infrastructure improves trade in the town by $74 \%$. This shows that infrastructure is a major factorial booster of trade in the area. The above model has also been determined to account for $54.7 \%$ of the total variation that take place in trade in Narok Town.

$$
\text { Economic_Development }=0.172 \text { Health }+0.379 \text { Infrastructure }+0.352 \text { Trade }
$$

From the above model it can be seen that $100 \%$ improvement that takes place in Health, Infrastructure and Trade, results into $17.2 \%, 37.9 \%$ and $35.2 \%$ improvement in the economy of Narok Town respectively. This means that all these factors together if improved by $100 \%$ will result into $90.3 \%$ economic development of Narok Town. The model contributes to $66.4 \%$ of the variation in the economic development of Narok Town.

\section{Conclusion}

1) Not much has been done by the county on the improvement of the status of health, trade and infrastructure.

2) Among all the indicators used in the study to indicate the economic development of the town, trade is the one that is considered by the residents as to have developed in many aspects than all the other indicators.

3 ) It is found out that the developments that took place in health, trade and infrastructure, greatly impact on the economic development of the town.

4) The ratings of the developments that takes place in health, trade and infrastructure can be used to rate the general economic development that takes place in the town.

5) Majority of the resident do consider that the economy of the county has not developed since the establishment of the Narok County government.

\section{Recommendation}

The county government should try and improve the status of infrastructure, health, and trade, this as a result will aid in elevating the status of the economy of Narok Town in general.

Other researchers should check on the other indicators like education, agriculture and environment to identify if there is significantly impact on them due to the introduction of County government. There is also need to examine these parameters after a specified period of time let say 5 years to give the County government's information on which specific indicators/parameters of economic development they should improve.

\section{Acknowledgements}

I would like to take this chance to thank the Almighty God for his guidance and support throughout my studies and during my undertaking of this study. I would also like to acknowledge my supervisors, Dr. Samuel Muthiga for their guidance in doing this study. I would also like to appreciate all those individuals who aided me in one way or the other in the completion of this research study.

\section{References}

[1] Sankale O.; Influence of government intervention measures on girl child completion of primary education in mao division, narok county, kenya (2014); UON (2014); Nairobi-Kenya.

[2] CRECO; Kenya's economy (2012); From, https://www.humanitarianresponse.info/sites/www.humanitari anresponse.info/files/documents/files/CRECO_2012.pdf.

[3] Transition Authority; A Guide to the Mandates and Procedures of County Governments in Kenya (2013); Transitional Authority \& EISA (2013); Nairobi - Kenya.

[4] Angie Mohr; Factors affecting Economic Development (2016)

[5] Wanzala, N., and Olutende, O., (2019). Role of devolution in health service delivery, health workforce and medical commodities acquisition: A review.

[6] World Bank, (2012). Devolution without disruption: Pathways to a successful new Kenya.

[7] Kasyula, P., (2018). Influence of devolution framework on democratic governance process in Kenya.

[8] Mwenda, K., (2010). Economic and administrative implications of the devolution framework established by the constitution in Kenya.

[9] KIRA \& Red Cross; Narok Secondary Data Review (2014); KIRA \& Red Cross (2014); Narok - Kenya.

[10] Gathu, J., (2014). Analyzing the impact of devolution on economic development potentialities in Kenya. International affairs and global strategy. Vol. 26. 
[11] Ntara, C., (2010). Devolution and expected impact in Kenya. International journal of professional practice. Vol. 4.

[12] Nzau, M., (2013). Effects of devolved funds on economic growth in Kenya: Empirical investigation (1993 - 2012).

[13] Njuguna, C., (2012). Devolution and its effects on the community: A cross sectional study of Githunguri constituency in Kiambu County.

[14] Ngaruiya, K., (2019). The political economy of devolution: Rethinking participatory governance for development from the bottom in Kenya.

[15] Aiden, G., and Mageniss, E., (2009). The impact of devolution on everyday life, 1999 - 2009: The case of cross-border commerce. Institute for British -Irish studies University College Dublin.

[16] Mbugua, F., (2013). Devolution and its impacts on regional trade in east Africa: A case study of Kenya.

[17] Kubai, J., (2019). Impact of devolution of health care systems in Kenya: A case study of Meru county health facility.

[18] Kobia, A., (2016). Influence of devolution of government services delivery on provision of health care: A case of level five hospital in Meru County, Kenya.

[19] NDMA; Narok County Drought Early Warning Bulletin For February (2016). 